\title{
Cost Economics and Suitability of Different Management Practices in Minimizing Damage by Wildboars in Groundnut
}

\author{
R. Prasanna Lakshmi*, P. Bala Hussain Reddy, P. Ganesh Kumar, \\ C.H. Bhargava Rami Reddy and A. Srinivasulu
}

\author{
Krishi Vigyan Kendra, Kalikiri, Chittoor, Andhra Pradesh, Acharya N G Ranga Agricultural \\ University, Guntur, Andhra Pradesh, India \\ *Corresponding author
}

\author{
A B S T R A C T
}

Wild boars are present in all continents except Antarctica and greatly affect community structure and ecosystem function. Especially damage to agricultural crops like groundnut,

\section{Keywords}

Crop damage, Wildboars, Technologies, Cost economics

Article Info

Accepted:

23 June 2017

Available Online:

10 July 2017 maize, jowar etc by wild boars is enormous and widespread. Earlier the damage by wild boars was high in crop fields nearer to forest areas now they are damaging crops in roadside villages also. Among the field crops, groundnut is severely damaged by wild boars i.e. during sowing and from pod formation stage to harvesting stage. In Chittoor district of Andhra Pradesh where 1.3 lakh hectares of groundnut is being cultivated during kharif, wild boars are the major havoc than any other pest in most of the areas. The present study focuses on cost economics and suitability of ITKs followed by farmers and also technologies recommended by researchers to minimize damage caused by wild boars. Generally farmers used to follow tying of sarees around field and tying of empty glass bottles along with stone/bolt which minimizes crop damage by wild boars up to $15-20 \%$. Different methods recommended by All India Network Project on Vertebrate pest management were demonstrated by KVK, Kalikiri scientists. Among all the methods tying of 3-4 rows of GI wire was found to cost effective and better in minimizing crop damage by wild boar. During rabi, growing of safflower around groundnut field was best in minimizing crop damage by wild boars.

\section{Introduction}

In India, agricultural production is mainly affected by insect pests, plant diseases and weeds to a greater extent. In recent times, fauna mainly consisting of mammals with special reference to rodents, wild boars, elephants and monkeys are attaining pest status and in certain cases a huge damage is being encountered due to some of these vertebrate pests (Vasudeva rao et al., 2015). Among them, wildboar is the most problematic species causing significant crop damage across different agro climatic zones

of the country. Wildboar (Sus scrofa) is a native mammalian species of Western Europe as well as of Northern Africa (Dobson 1998). The basic reason for such unexpected abrupt raise in their populations can be attributed to degradation of natural habitats, nonavailability of preferred dietary items in natural habitats. Deforestation resulted in the decline of the natural predators for wild boars like tigers, wolf, jackal etc (Khokhar and Rizvi, 1998) there by indirectly contributing to the phenomenal raise in the wildboar 
populations. Over exploitation of forest resources by the mankind forced wildboars out of their natural habitat and compelled them to depend on cultivated crops such as groundnut, paddy, maize, sorghum, fruits and vegetables.

Wildboar have certain characteristics like non -specific diet, large litter size that allow them to inhabit broad range habitats. Wildboars are considered opportunistic omnivores as they can eat and digest wide range of food. They have seasonal and regional differences in their diet based on the availability of food and changes in crops (Schley and Roper 2003).

Wildboar have high reproductive rate with an average litter of five piglets (Millar and Zammuto 1983) and they can have two litters a year (Bieber and Ruf 2005). Another biological factor regarding the reproduction of wildboars that results in its successful invasive nature is that $S$. scrofa have the ability to breed year round (Coblentz and Baber 1987). A year round mating season, particularly in an animal that produces five piglets a litter can result in a massive wildboar population that is extremely difficult to control. The wildboar has the ability to increase its population size by $150 \%$ annually (Massei and Genov, 2004). An increasing population allows the wildboar to expand over broad ranges and to take away habitats of native species.

The intensity of damage depends on population density, cropping pattern, extent of crop area, season and stage of the crop. The damage caused by wildboar is more alarming than their actual feeding in the crop. Farmers have developed antagonistic attitude towards wildboar and pushes towards retributive killings that have a substantial impact on the wildboar population undermining the conservation efforts (Woodroffe et al., 2005). Therefore, reducing antagonism caused mortality is an important strategy for conservation of wildboars. Hence, demonstrations were conducted at Krishi Vigyan Kendra, Kalikiri operational area with a view to create awareness about different methods developed by researchers to minimize wildboar damage.

\section{Materials and Methods}

Demonstrations were conducted in farmers' fields during the year 2016 (Kharif and Rabi) in KVK operational area. Different methods recommended by All India Network Project on Vertebrate pest management, Hyderabad were demonstrated in farmers' fields. Their performance with respect to restricting wildboar movement and cost economics were calculated against traditional methods followed by farmers to deter the wildboar movement.

\section{Results and Discussion}

\section{ITKs used by farmers to minimize wildboar damage}

\section{Sarees method}

This is generally followed by farmers, which has a behavioral background with respect to wildboars. By arranging different colored old sarees around the crop, the animal may not able to push through soft cloth when the snout comes into contact as it is the most sensitive part of its body.

But in recent times, according to farmers, if sounder of boars arrive, then they enter the crop field even though sarees tied around field.

Tying of empty glass bottles along with bolt/stone around the field

Farmers in KVK operational area also follow this method to restrict wildboar movement. In this method, empty glass bottles are tied 
around the field to which a small bolt or stone is attached. When wind movement is there, stone/bolt touches the glass bottle and produces sound to scare away the wildboars from damaging the crops.

This method is not that much effective because heavy wind movement may not be there all the time.

But when wind movement is there, this method is effective against wildboars thereby minimizing the crop damage up to $30-35 \%$.

Technologies recommended by AINP on vertebrate pest management

Arrangement of three rows of cotton nawar soaked in kerosene

Cotton nawar is soaked in kerosene solution and wooden poles were planted around the field at a distance of $1 \mathrm{~m}$.

Kerosene soaked cotton nawar is tied to these wooden poles around the field in 3 rows by keeping $1 \mathrm{ft}$ distance between the rows. Kerosene smell restricted wildboar movement for 7-8 days.

Amount spent to tie kerosene soaked cotton nawar in 3 rows around 1 acre field

Kerosene soaked

Cotton nawar (15 rolls)

-Rs. 3000

Labour wages

- Rs. 1200

Wooden poles

- Rs. 600

Total amount

- Rs. 4800

Even though wildboar movement is restricted, this method requires more expenditure which may not be affordable by small and marginal farmers.

After 7-8 days the nawar should be soaked in kerosene and again tied around field which was a cumbersome process to the farmers. Hence farmers were not shown much interest in adopting the technology.

Cost of wooden poles was not taken into consideration as tomato is the major crop KVK jurisdiction and eucalyptus sticks used for tomato staking were again used for this purpose also. Same is the case with other methods also.

\section{Arranging three rows of coconut rope smeared with sulphur and pig oil}

Coconut coir rope is arranged in three rows around the field with the support of wooden poles which are placed at $1-2 \mathrm{~m}$ distance. Sulphur is mixed in oil at certain proportion that make into semi solid suspension.

Then sulphur and oil mixture is smeared on already tied coconut rope.

This mixture smell acted as a repellent to wildboars which were unable to enter crop field.

This mixture is applied 3 times on coconut rope at 10-12days interval to get good results.

Amount spent to tie sulphur applied coconut coir rope in 3 rows around 1 acre field

$\begin{aligned} & \text { Sulphur } \\ & \text { Pig oil }-\end{aligned} \quad$ Rs. 1500
$\begin{aligned} & \text { Labour wages }-800 \\ & \text { Coconut coir rope }\end{aligned}$
$\begin{aligned} & \text { Total amount - Rs.4200 } \\ & \text { Rs. } 1000\end{aligned}$

This method is successful with respect to damage caused by wildboar but availability of pig oil is a constraint in adopting this method and application of sulphur and pig oil mixture for 2-3 times in larger areas is laborious. 
Tying of empty glass bottles along with bolt/stone around the field
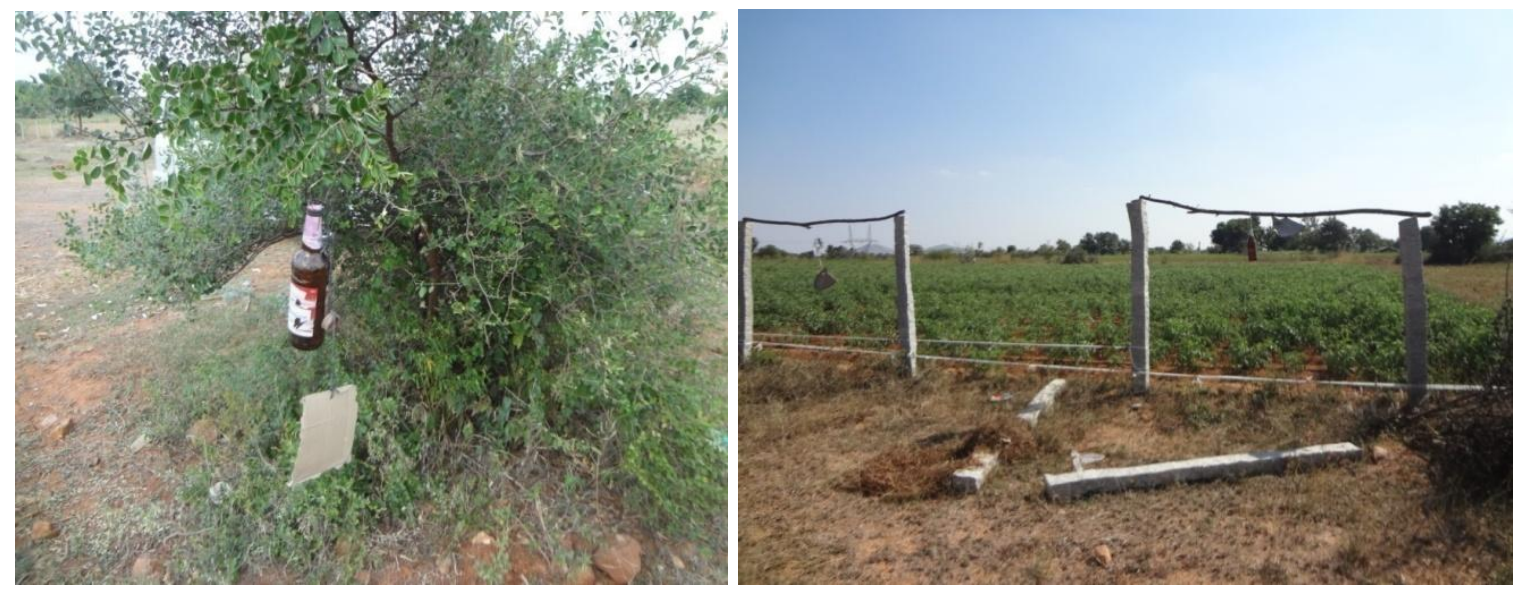

Tying of kerosene soaked cotton nawar in 3 rows around field

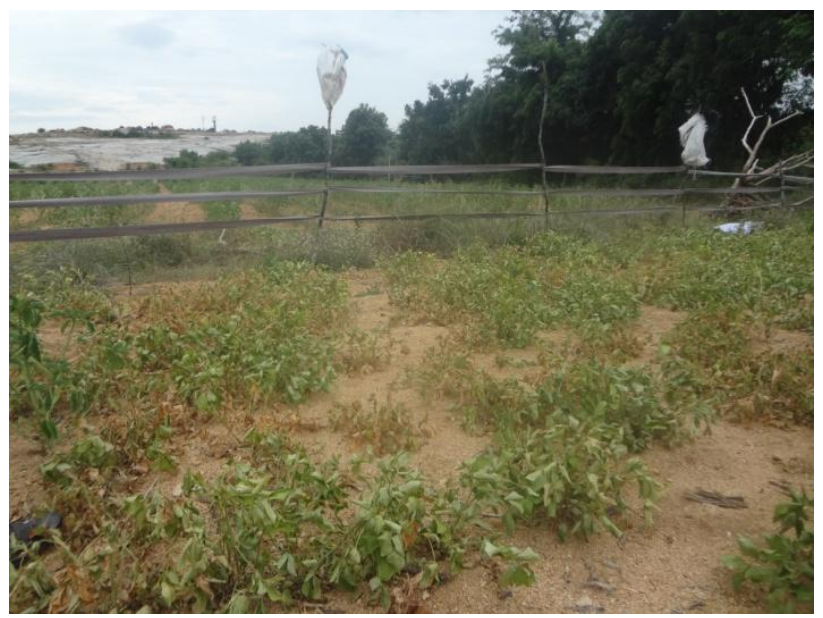

Arranging three rows of coconut rope smeared with sulphur and pig oil

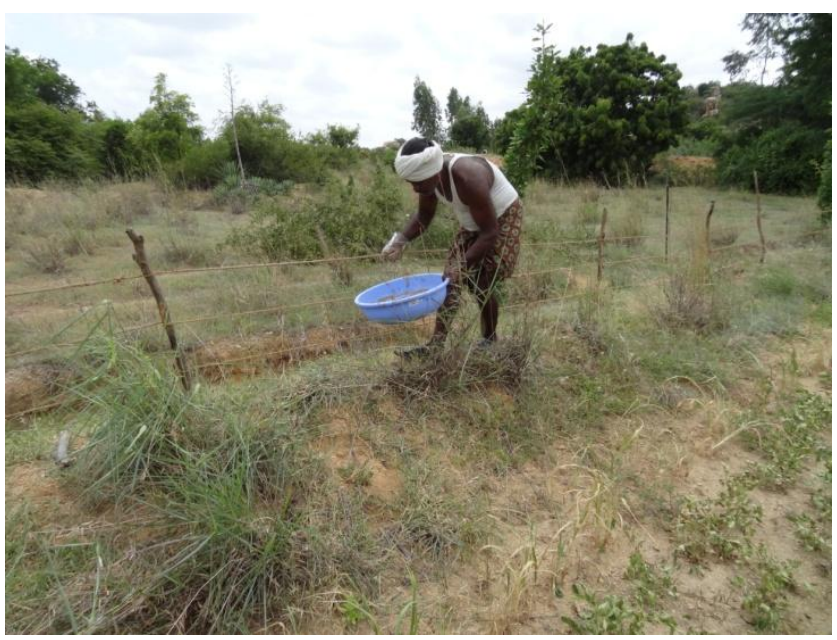


Arranging phorate granules around crop field

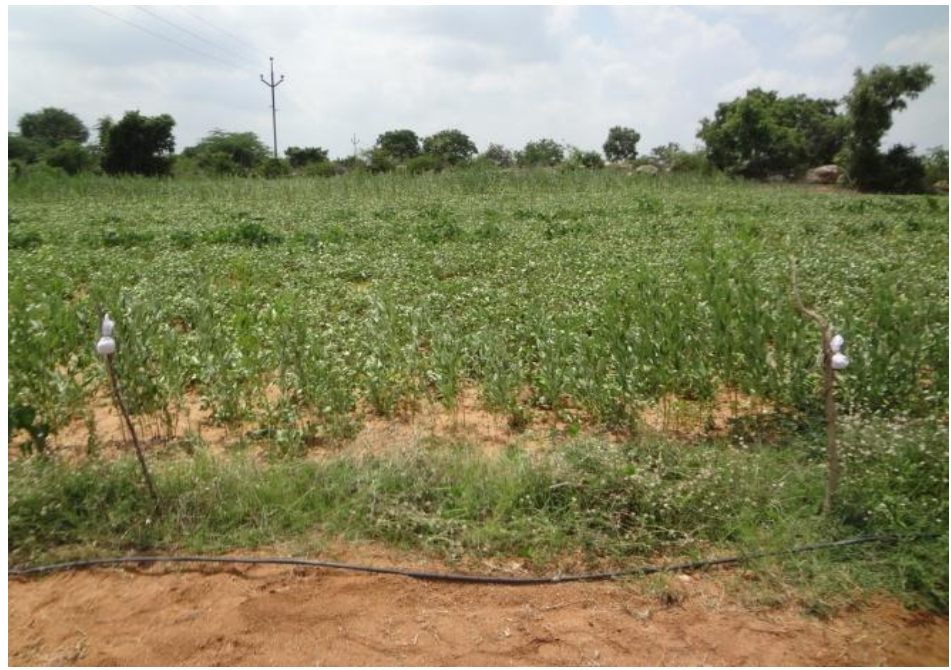

Tying of GI wire in 3 rows

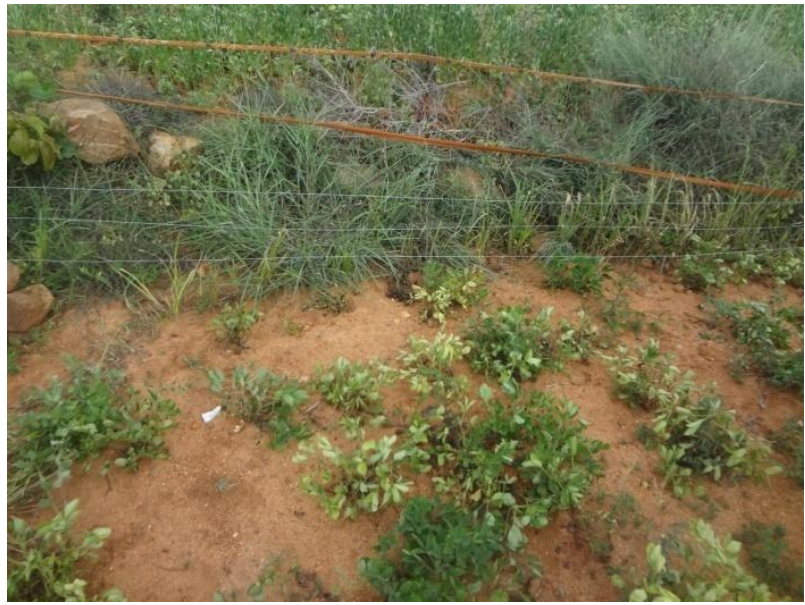

Tying 5rows of nylon (trellising) wire

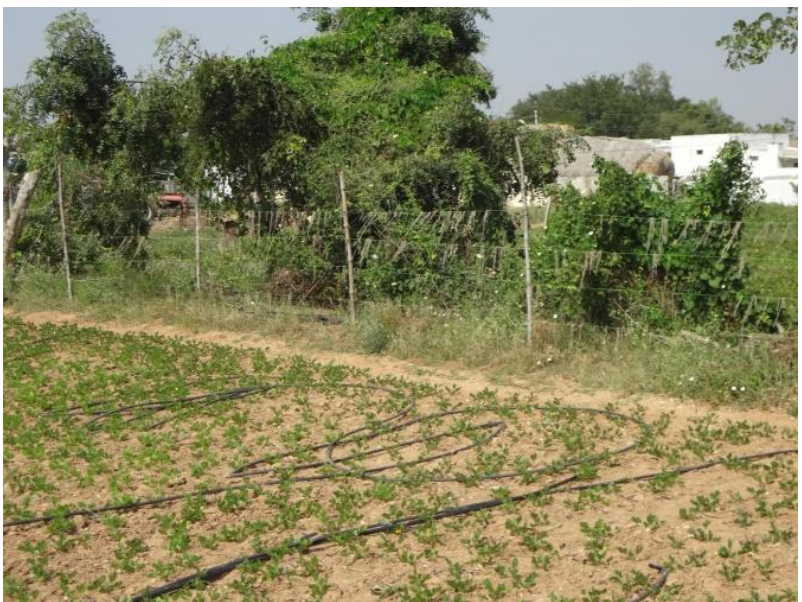

Tying of tomato trellising wire in 3 rows

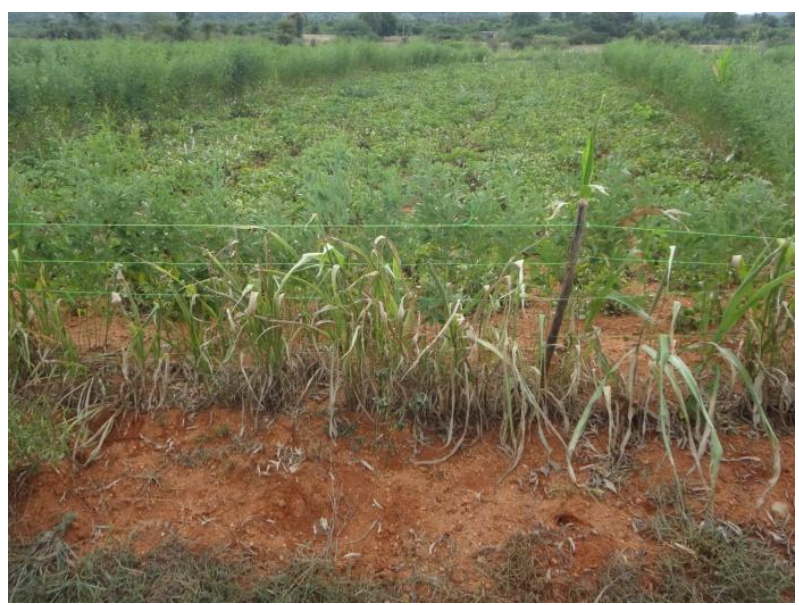

Safflower grown around groundnut field

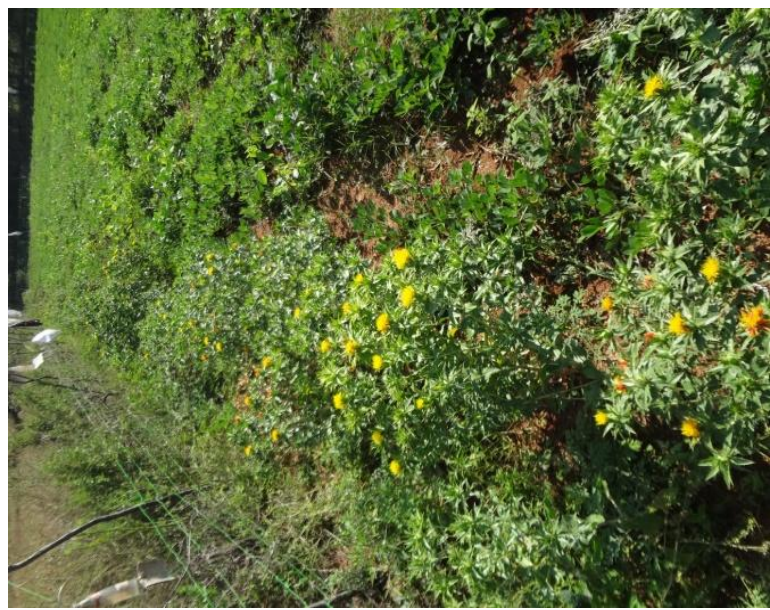




\section{Arranging phorate granules around crop field}

Wooden poles were planted around crop field at $1-2 \mathrm{~m}$ distance. Phorate granules and sand mixed in 1:5 ratio and $50-60 \mathrm{~g}$ of mixture is kept in perforated cloth and tied to wooden poles at $60-70 \mathrm{~cm}$ height. This works on the principle of strong smell of phorate granules which is more concentrated than crop smell and wildboars cannot detect the crop. This method was effective for about 6-7days, after that wildboar entered the crop field and damaged the crop.

\section{Tying of GI wire in three rows around the field}

Wooden poles were arranged around the crop field at $1 \mathrm{~m}$ distance then GI wire is tied in three rows from base to top. This acts as a fence and restricts wildboar movement into the crop field.

Amount spent to tie GI wire in 3 rows around 1 acre field

$\begin{array}{lc}\text { GI wire: } 8 \mathrm{~kg}- & \text { Rs. } 880 \\ \text { Labour wages: }- & \text { Rs. } 600 \\ \text { Total amount } & - \text { Rs. } 1480\end{array}$

GI wire acted as a good fence but instead of three rows farmers tied 5 rows of GI wire i.e. $1 / 2 \mathrm{ft}$ from base then $1 \mathrm{ft}$ distance between the rows for better protection from piglets and large wildboars respectively. For this additional expenditure of Rs.300/- was spent by the farmers and it gave good protection from wildboars.

KVK scientists have tried nylon wire that is used for tomato trellising / staking instead of GI wire which is cheaper than GI wire and due to its less weight, its requirement is also less when compared to GI wire.
Amount spent to tie trellising wire in 3 rows around 1 acre field

Trellising wire: $5 \mathrm{~kg}-500$

Labour wages $\quad-600$

Total amount $\quad-1100$

Among all methods tying of 5 rows of trellising wire found to be best in minimizing wildboar damage and cost effective to the small and marginal farmers also and farmers are also interested to adopt this method.

During rabi, 2016-17 safflower crop is grown as guard crop or border crop in 3-4 rows with $30 \times 15 \mathrm{~cm}$ spacing around groundnut to restrict wildboars entering field. This was found to be best among all the methods due to its thorny nature it causes inconvenience to wildboars. Because of this extent of damage is minimized by $60-70 \%$. Farmers stored the seed of safflower for next rabi and they are willing to adopt the technology in combination with tying of trellising wire to minimize crop damage by wildboars.

It can be concluded that the various traditional methods followed by farmers to minimize wildboar damage to crops are effective to some extent only without any cost involved. Hence, there is a need to popularize of suitable cost effective technologies to restrict wildboars entering crop fields. Among all the methods, tying of 5 rows of nylon wire used for tomato trellising or GI wire during kharif and during rabi, safflower as a guard crop in combination with GI wire or trellising wire found to be best in minimizing crop damage by wildboars.

\section{References}

Bieber, C., and T. Ruf. 2005. Population dynamics in Wildboar Sus scrofa: ecology, elasticity of growth rate and implications for the management of 
pulsed resource consumers. Journal of Applied Ecology 42(6):1203-1213.

Coblentz, B.E., and D.W. Baber. 1987. Biology and control of feral pigs on Isla Santiago, Galapagos, Equador. Journal of Applied Ecology 24:403-418.

Dobson, M., 1998. Mammal distributions in the western Mediterranean: the role of human intervention. Mammal Review 28(2):77-88.

Khokhar A R., and Rizvi S W A 1998. Productivity enhancement of rice crop yield through prevention of losses due to wildboars in Pakistan.

Massei, G., and P.V. Genov. 2004. The environmental impact of Wildboar. Galemys 16:135-145.

Millar, J.S., and R.M. Zammuto. 1983. Life histories of mammals: an analysis of life tables. Ecology 64(4):631-635.

Schley, L., and T.J. Roper. 2003. Diet of Wildboar (Sus scrofa) in Western Europe, with particular reference to consumption of agricultural crops. Mammal Review 33(1):43-56

Vasudeva rao, V., Naresh, B., Ravinder reddy, V., Sudhakar, C., Venkateswarlu, P., and Ramarao, D. 2015. Traditional management methods used to minimize wildboar (Sus scrofa) damage in different agricultural crops at Telangana state, India. International journal of multidisciplinary research and development 2(2):32-36.

Woodroffe, R., Thirgood, S., and Rabinowitz, A. 2005. People and Wildlife, conflict or Coexistence? Cambridge University Press, Cambridge, UK.

\section{How to cite this article:}

Prasanna Lakshmi, R., P. Bala Hussain Reddy, P. Ganesh Kumar, C.H. Bhargava Rami Reddy and Srinivasulu, A. 2017. Cost Economics and Suitability of Different Management Practices in Minimizing Damage by Wildboars in Groundnut. Int.J.Curr.Microbiol.App.Sci. 6(7): 25512557. doi: https://doi.org/10.20546/ijcmas.2017.607.301 